\title{
RESPON NAUNGAN TERHADAP PERTUMBUHAN DUA VARIETAS NILAM (Pogostemon cablin Benth.)
}

\author{
Rusdi Faizin ${ }^{1)}$,Putra Susila ${ }^{1)^{*}}$ \\ Email: putrasusila558@gmail.com
}

\begin{abstract}
ABSTRAK
Tanaman Nilam membutuhkan cahaya yang relatif sedikit, terutama pada awal pertumbuhan setek tanaman. Untuk mejamin pertumbuhan bibit tanaman nilam perlu diberi pelindung, baik pelindung dari tanaman maupun pelindung buatan. Intensitas cahaya yang rendah mampu meningkatkan parameter pertumbuhan tanaman nilam. Penelitian ini bertujuan untuk mengetahui pengaruh naungan terhadap pertumbuhan nilam varietas Tapak Tuan, dan varietas Lhokseumawe. Penelitian ini dilaksanakan di kebun percobaan Fakultas Pertanian Universitas Teuku Umar Meulaboh Kabupaten Aceh Barat pada September 2016 s/d April 2017. Bahan yang digunakan yaitu stek tanaman nilam, paranet $25 \%$ (75\% cahaya diterima), paranet 50\% (50\% cahaya diterima), dan tanpa paranet. Pupuk yang digunakan adalah, pupuk organik, Urea, SP36 dan KCl, zat perangsang tumbuh yaitu grow tone. Penelitian ini menggunakan rancangan petak terpisah (split plot design). Petak utama adalah naungan dan anak petak adalah varietas nilam yaitu varietas Tapaktuan dan varietas Lhokseumawe. Adapun parameter yang diamati yaitu tinggi tanaman, diameter pangkal batang, jumlah cabang, jumlah daun dan luas daun. Pemberian naungan 50\% memberi pengaruh terhadap tinggi tanaman, diameter pangkal batang, jumlah daun dan luas daun. Sedangkan varietas Lhokseumawe menunjukkan peningkatan pertambahan tinggi tanaman, diameter pangkal batang, jumlah cabang, jumlah daun dan luas daun.
\end{abstract}

Kata kunci: pertumbuhan, naungan, varietas, cahaya

\begin{abstract}
Patchouli plants require a less lighting, especially at the beginning of their growth. To ensure of patchouli cuttings grow, the plant need The shading can be from plant shade or artificial shade. Low light intensity can improve given shading. patchouli growth parameters. This study aims to determine the effect of shade on patchouli growth in Tapak Tuan varieties, and Lhokseumawe varieties. This research was conducted at the Meulaboh Teuku Umar University Faculty of Agriculture experimental park in West Aceh Regency in September 2016 until April 2017. The materials used were patchouli cuttings, $25 \%$ paranet (75\% light received), paranet 50\% (50\% light received ), and without paranet. Fertilizers used are, organic fertilizer, Urea, SP36 and KCl, growing stimulants, namely grow tone. This study uses a split plot design. The main plot is shade and subplot are patchouli varieties namely Tapaktuan variety and Lhokseumawe variety. The parameters observed were plant height, stem base diameter, number of branches, number of leaves and leaf area. 50\% shade gives an influence on plant height, stem diameter, number of leaves and leaf area. While the Lhokseumawe variety showed an increase in plant height, stem diameter, number of branches, number of leaves and leaf area.
\end{abstract}

Keywords: growth, shade, variety, sunlight

${ }^{1}$ Universitas Teuku Umar Meulaboh 


\section{Pendahuluan}

Nilam (Pogostemon cablin Benth) merupakan salah satu tanaman penghasil minyak atsiri Indonesia. Minyak nilam atau patchouli oil merupakan salah satu komoditas andalan sebagai sumber devisa dan pendapatan petani. Areal pertanaman nilam di Indonesia tahun 2012 seluas $31.155 \mathrm{Ha}$ dengan produksi rata-rata 2.648-ton. Kondisi ini mengalami penurunan sehingga pada tahun 2016 luasan tanaman nilam menjadi 18.562 ha dengan produksi rata-rata 1.954 ton. Sentra produksi tanaman nilam tersebar di daerah Aceh, Sumatera Utara, Sumatera Barat, Bengkulu, Jawa Barat dan Jawa Tengah. Masalah utama yang dihadapi adalah rendahnya produktivitas dan mutu minyak (Dirjenbun, 2017).

Prospek ekspor komoditi nilam masih terbuka luas dan cukup besar, seiring dengan semakin tingginya permintaan terhadap bahan baku parfum, kosmetik, farmasi dan interaksi trend mode dunia, serta belum ditemukannya barang substitusi essential oils yang bersifat pengikat (fixatif) dalam industri parfum dan kosmetika (Mangun et al. 2012)

Tanaman nilam menghendaki kondisi lingkungan yang optimum untuk pertumbuhannya. Kondisi lingkungan terutama cahaya akan sangat mempengaruhi pertumbuhan dan produksi minyak nilam (Imran, 1994). Agar pertumbuhan dan produksi minyak nilam dapat di peroleh secara optimal, tanaman nilam memerlukan intensitas penyinaran berkisar antara 75 $100 \%$. Nilam yang ditanam di bawah naungan akan tumbuh lebih subur, daun lebih lebar dan tipis serta hijau, tetapi kadar minyaknya rendah. Tanaman nilam yang ditanam di tempat terbuka, pertumbuhan tanaman kurang rimbun, habitus tanaman lebih kecil, daun agak kecil dan tebal, daun berwarna kekuningan dan sedikit merah, tetapi kadar minyaknya lebih tinggi (Nuryani et al., 2005).

Pengaruh intensitas cahaya terhadap pertumbuhan dan perkembangan tanaman berhubungan erat dengan proses fotosintesis. Dalam proses ini 84nergy cahaya diperlukan untuk berlangsungnya penyatuan $\mathrm{CO} 2$ dan air untuk membentuk karbohidrat. Semakin besar jumlah 84nergy yang tersedia akan memperbesar jumlah hasil fotosintesis sampai dengan optimum (maksimal). Untuk menghasilkan berat kering yang maksimal, tanaman memerlukan intensitas cahaya penuh.

Penggunaan varietas yang toleran merupakan salah satu pilihan teknologi yang paling efisien danmurah. Saat ini telah dilepas varietas unggul nilam yaitu varietas Sidikalang, Tapak Tuan, dan Lhok seumawe (Nuryani et. Al, 2005).

\section{Metode Penelitian}

\section{Waktu dan Tempat}

Penelitian dilaksanakan di Kebun Percobaan Fakultas Pertanian UTU pada bulan September 2016 sampai dengan bulan April 2017.

\section{Bahan dan Alat}

Bahan yang digunakan yaitu tanaman nilam dalam bentuk stek varietas Tapak Tuan, dan varietas Lhokseumawe, paranet, pupuk organik, Urea, SP36 dan $\mathrm{KCl}$, ZPT growtone, bambu, tali dan plastik bening

Alat-alat yang digunakan cangkul, sekop, pisau, ember, jangka sorong, kamera digital, Lux Meter, kertas 84 millimeter, Meteran kain, meteran kayu, penggaris dan timbangan analitik.

\section{Metode Penelitian}

Penelitian ini dilaksanakan dengan melakukan penanaman nilam dengan persentase perlakuan naungan, 
yaitu tanpa naungan, naungan paranet $25 \%$, dan naungan paranet $50 \%$. Perlakuan naungan diberikan sejak tanam sampai selesai penelitian. Taraf naungan diperoleh dari pengukuran jumlah cahaya yang masuk pada kondisi terbuka dan kondisi naungan pada saat bersamaan dengan menggunakan dua buah Lux meter. Sedangkan varietas terdiri dari dua varietas nilam yaitu varietas Tapaktuan dan varietas Lhokseumawe. Jumlah plot yang dibutuhkan sebanyak 18 plot dengan 3 ulangan. Jarak antar tanaman $50 \times 100$ $\mathrm{cm}$, sehingga diperoleh jumlah tanaman 648 tanaman.

Penelitian menggunakan rancangan petak terpisah (split plot) dengan pola 85actorial yaitu petak utama; tanpa naungan (N0), naungan $25 \% \quad(\mathrm{~N} 1)$ dan naungan $50 \%$ (N2). Sedangkan anak petak adalah varietas terdiri dari varietas tapaktuan, lhokseumawe dan sidikalang.

\section{Parameter pengamatan}

Parameter yang diamati adalah: tinggi tanaman $(\mathrm{cm})$, Diameter pangkal batang (mm), Jumlah cabang (batang), Jumlah daun (helai) dan Luas Daun $\left(\mathrm{cm}^{2}\right)$.

\section{Hasil Dan Pembahasan}

\section{Pertambahan Tinggi Tanaman}

Hasil penelitian menunjukkan bahwa perlakuan naungan dan varietas berpengaruh nyata terhadap pertambahan tinggi tanaman nilam umur4, 8, 12 dan 16 MSPT.

Tabel 1. Pertambahan tinggi tanaman umur4, 8, 12 dan 16 MSPT akibat perlakuan naungan $(\mathrm{N})$ dan varietas tanaman $\mathrm{P} 1$ (Tapaktuan),P2 (Lhokseumawe)

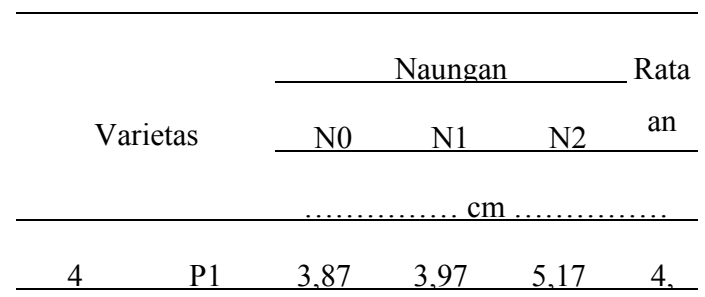

\begin{tabular}{|c|c|c|c|c|c|}
\hline MSPT & P2 & 4.78 & 5.39 & 6.24 & 5. \\
\hline & Rataz & $4.32 \mathrm{~b}$ & $4.68 \mathrm{~b}$ & $5.70 \mathrm{a}$ & \\
\hline 8 & P1 & 8.49 & 14.41 & 20.59 & 14 \\
\hline MSPT & P2 & 13,25 & 16,23 & 21,02 & 16 \\
\hline & Ratac & 10.87 & $15,32 \mathrm{~b}$ & 20,80 & \\
\hline 12 & P1 & 16,94 & 29,97 & 34,98 & 27 \\
\hline MSPT & P2 & 23,86 & 36,34 & 42,91 & \\
\hline & Ratac & $20.40 \mathrm{~b}$ & $33,16 \mathrm{a}$ & 38,94 & \\
\hline 16 & P1 & 20,66 & 35,30 & 41,81 & 32 \\
\hline MSPT & P2 & 26.53 & 41.79 & 52.68 & \\
\hline $\begin{array}{l} \\
\text { Keteran } \\
\text { pada ko } \\
\text { P } \leq=0,05 \\
\text { N0 : Tar } \\
\text { N1 : Na } \\
\text { N2 : Na }\end{array}$ & $\begin{array}{l}\text { Ratac } \\
\text { :Ang } \\
\text { n yan } \\
\text { Jji BN } \\
\text { Naur } \\
\text { san } 25\end{array}$ & $23,60 \mathrm{co}$ & $\begin{array}{l}38,55 \\
\text { uti olel }\end{array}$ & $\frac{47,25}{\text { uruf y }}$ & \\
\hline
\end{tabular}

Perlakuan naungan 50\% menunjukkan tinggi tanaman lebih tinggi, bila dibandingkan dengan perlakuan naungan $25 \%$ dan tanpa naungan.Tanaman nilam pada kondisi ternaungi selalu berupaya mencari cahaya, sehingga batang menjadi memanjang. Menurut Chenet al. (2015) cahaya adalah salah satu faktor lingkungan paling penting yang mempengaruhi kelangsungan hidup tanaman, pertumbuhan dan reproduksi. Pencahayaan yang cukup memadai dapat meningkatkan tinggi tanaman.

Intensitas cahaya menentukan suhu daun dan keseimbangan air, berhubungan erat dengan aktivitas fotosintesis dan transpirasi, sehingga secara langsung akan berpengaruh terhadap pertumbuhan tanaman seperti pemanjangan batang dan pembentangan daun (Agalave, 2017). Hasil penelitian Setiawan dan Sukamto (2016) menunjukkan bahwa tinggi tanaman nilam yang ditanam di bawah naungan 55\% lebih tinggi dibandingkan dengan yang ditanam tanpa naungan 
Varietas Lhokseumawe menunjukan pertambahan yang lebih tinggi dari varietas Tapaktuan, hal ini diduga bahwa lingkungan di sekitar tanaman yang ternaungi mendukung untuk pertumbuhannya ini didukung oleh adanya naungan yang menciptakan kondisi lingkungan yang mudah untuk penyesuainnya.

Setiap varietas yang telah diuji memiliki daya adaptasi dan pertumbuhan yang berbeda. Perbedaan sifat genetik terdapat dari masing-masing varietas mempengaruhi segi adaptasi terhadap lingkungan sehingga terdapat respon yang bervariasi. Menurut Adi nugraha et al (2006), perbedaan pertumbuhan dipengaruhi oleh asal sumber bibit dan perbedaan lingkungan, juga dikarenakan oleh perbedaan sifat genetik yang dibawa oleh masing-masing asal sumber bibit. Salah satu ekspresi dari sifat genetik adalah kemampuan beradaptasi terhadap lingkungan.

\section{Diameter pangkal batang}

Hasil penelitian menunjukkan bahwa perlakuan naungan dan varietas berpengaruh nyata terhadap pertambahan diameter pangkal batang tanaman nilam umur4, 8, 12 dan 16 MSPT.

Tabel2.Pertambahan diameter pangkal batang umur 4, 8, 12 dan 16 MSPT akibat perlakuan naungan $(\mathrm{N})$ dan varietas tanaman P1 (Tapaktuan), P2 (Lhokseumawe)

\begin{tabular}{cccc}
\multirow{2}{*}{ Varietas } & \multicolumn{3}{c}{ Naungan } \\
\cline { 2 - 3 } & N0 & N1 & N2
\end{tabular}

$\mathrm{mm}$

\begin{tabular}{ccccccc} 
& P1 & 0,84 & 1,21 & 1,29 & $1,11 \mathrm{~b}$ \\
\cline { 2 - 6 } MSPT & P2 & 1,04 & 1,29 & 1,48 & $1,27 \mathrm{a}$ \\
\cline { 2 - 6 } & & Rataan & $0,94 \mathrm{~b}$ & $1,25 \mathrm{ab}$ & $1,38 \mathrm{a}$ & \\
\hline 8 & $\mathrm{P} 1$ & 3,12 & 3,10 & 3,92 & $3,38 \mathrm{~b}$ \\
\cline { 2 - 6 } MSPT & P2 & 3,16 & 3,78 & 4,13 & $3,69 \mathrm{a}$ \\
\hline
\end{tabular}

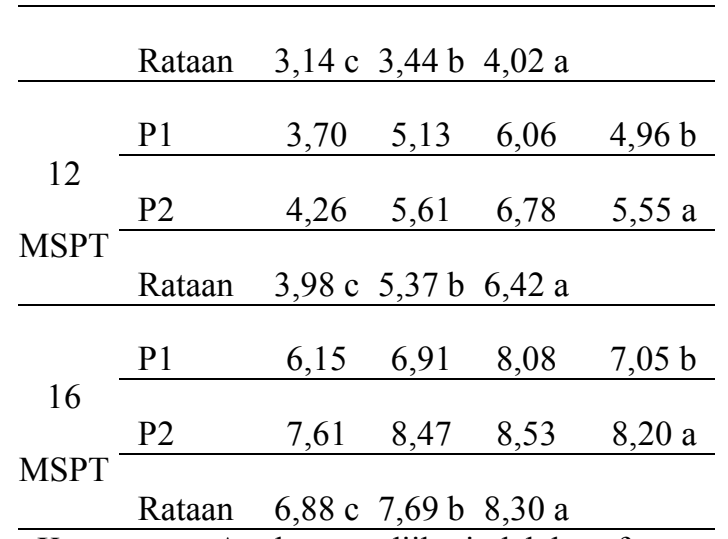

Keterangan :Angka yangdiikuti oleh huruf yang sama pada kolom yang sama tidak berbeda nyata pada taraf $\mathrm{P} \leq=0,05$ (Uji BNJ)

N0 : Tanpa Naungan,

N1 : Naungan $25 \%$,

N2 : Naungan 50\%

Perlakuan naungan 50\% menunjukkan diameter pangkal batang tanaman lebih besar, bila dibandingkan dengan perlakuan naungan $25 \%$ dan tanpa naungan. Menurut Haryanti (2008), tanaman yang ternaungi berusaha untuk meningkatkan pemanenan cahaya agar hasil fotosintat yang diperoleh tinggi sehingga dapat mendukung pertumbuhan.

Varietas

Lhokseumawe menunjukkan pertambahan diameter pangkal batangyang lebih baik dibandingkan dengan varietas Tapaktuan. Hal ini diduga kesesuaian lingkungan tumbuh terhadap varietas Lhokseumawe,

serta sinar matahari dengan intensitas cahaya yang kurang (ternaungi) pada varietas Lhokseumawe dapat meningkatkan diameter pangkal batang tanaman nilam.

Menurut Rahayu dan Harjoso (2011) pengaruh pertumbuhan tanaman sangat dipengaruhi oleh varietas, karena setiap varietas mempunyai sifat genetis, morfologis maupun fisiologis yang berbeda.

\section{Jumlah Cabang}

Hasil penelitian menunjukkan bahwa perlakuan naungan dan varietas berpengaruh nyata terhadap pertambahan 
jumlah cabang tanaman nilam umur4, 8 , 12 dan 16 MSPT.

Tabel 3. Pertambahan jumlah cabang umur 4, 8, 12 dan 16 MSPT akibat perlakuan naungan $(\mathrm{N})$ dan varietas tanaman $\mathrm{P} 1$ (Tapaktuan), P2 (Lhokseumawe)

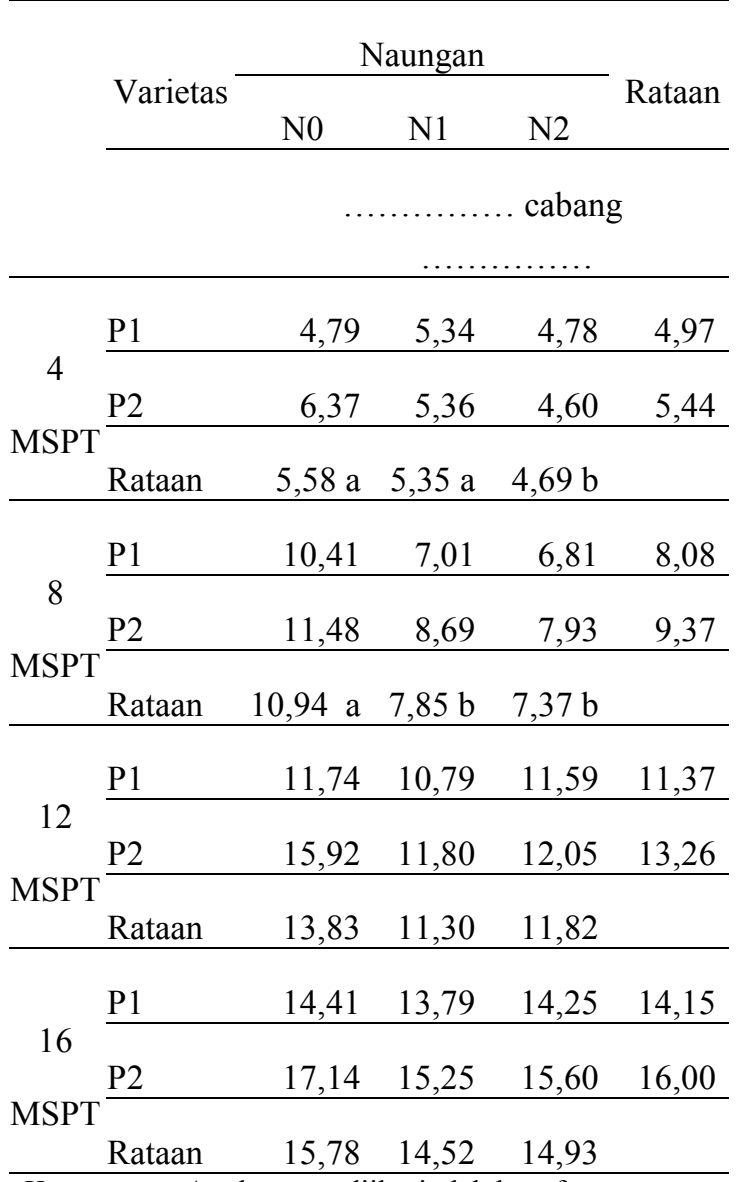

Keterangan :Angka yang diikuti oleh huruf yang sama pada kolom yang sama tidak berbeda nyata pada taraf $\mathrm{P} \leq=0,05$ (Uji BNJ)

N0 : Tanpa Naungan,

N1 : Naungan $25 \%$,

N2 : Naungan 50\%

Perlakuan tanpa naungan menunjukkan pertambahan jumlah cabang lebih banyak bila dibandingkan dengan perlakuan lainnya. Pertambahan cabang di sebabkan oleh kondisi lingkungan, pengaruh cahaya terhadap dominasi pucuk ini sering dikaitkan dengan perubahan kandungan atau komposisi hormon dan karbohidrat pada bagian pucuk tanaman. Perubahan ini dapat terjadi akibat pemacuan atau hambatan terhadap laju sintesis atau pengangkutan dari hormon, atau karbohidrat tersebut. Penelitian pada tanaman tembakau faktor fisik seperti cahaya mempengaruhi dominasi pucuk terutama pada cahaya merah mengurangi dominasi pucuk, terbukti dengan banyaknya cabang lateral yang tumbuh (Lakitan, 1996).

Sinar matahari dengan intensitas tinggi diduga menghambat sintesis hormon auksin di dalam jaringanmeristem pucuk,

sementara hormon sitokinin yang disintesis di ujung-ujung akar, produksinya tetap. Sebagai akibatnya maka nisbah konsentrasi hormon sitokinin/auksin meningkat dan melemahkan dominansi pucuk sehingga berakibat pada pemacuan pertumbuhan tunas-tunas lateral. Seperti dilaporkan Gardner et al. (1991), pembentukan kuncup liar dipacu oleh adanya sinergisme antara auksin dan sitokinin. Perpindahan sitokinin dari akar memacu pertumbuhan baru dari kuncup ketiak daun yang tersembunyi oleh dominansi ujung

\section{Jumlah Daun}

Hasil penelitian menunjukkan bahwa perlakuan naungan dan varietas berpengaruh nyata terhadap pertambahan jumlah daun tanaman nilam umur4, 8, 12 dan 16 MSPT.

Tabel 4. Pertambahan jumlah daun umur 4, 8, 12 dan 16 MSPT akibat perlakuan naungan (N) dan varietas tanaman (P) P1 (Tapaktuan), P2 (Lhokseumawe)

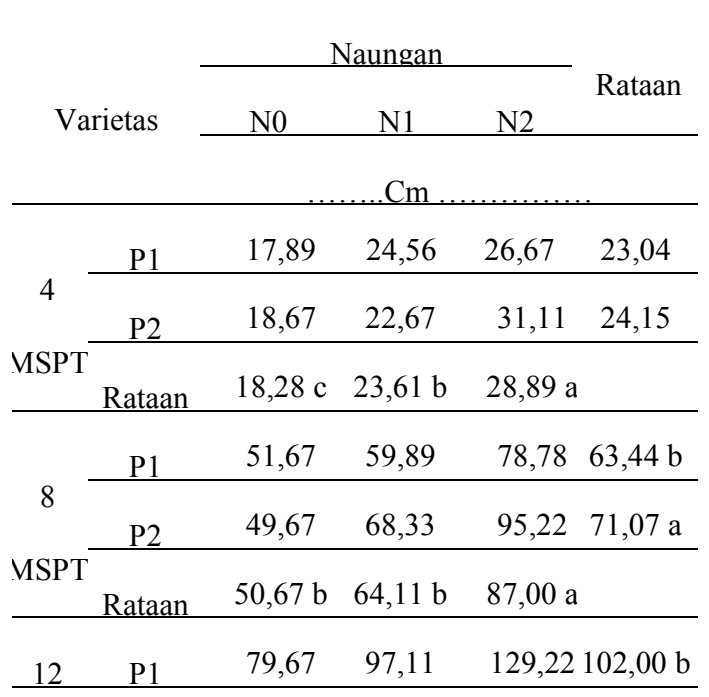




\begin{tabular}{|c|c|c|c|c|}
\hline \multirow[t]{2}{*}{ MSPT } & P2 & 75,89 & 146,78 & $180,44134,37 \mathrm{a}$ \\
\hline & Rataan & $77,78 \mathrm{c}$ & $121,94 \mathrm{~b}$ & 154,83 \\
\hline \multirow{2}{*}{16} & P1 & 98,89 & 126,45 & $177,89134,41 \mathrm{~b}$ \\
\hline & $\mathrm{P} 2$ & 98,89 & 208,78 & $218,55 \quad 175,41 \mathrm{a}$ \\
\hline MSPT & $\mathrm{R}$ & $98,89 \mathrm{~b}$ & 167,61 a & 198,22 \\
\hline
\end{tabular}

Keterangan : Angka yang diikuti oleh huruf yang sama pada kolom yang sama tidak berbeda nyata pada taraf $\mathrm{P} \leq=0,05$ (Uji BNJ)

N0 : Tanpa Naungan,

N1 : Naungan $25 \%$,

N2 : Naungan $50 \%$

Perlakuan naungan 50\%

diperoleh jumlah daun yang lebih banyak bila dibandingkan dengan perlakuan naungan $25 \%$ dan tanpa naungan. Pertambahan jumlah daun merupakan salah satu indikasi pertumbuhan vegetatif yang mengiringi pertambahan tinggi. Nuryani (2006) menyatakan bahwa semakin banyak jumlah cabang dan semakin panjang cabangnya, akan semakin banyak jumlah daun per cabang. Walaupun hasil penelitian menunjukkan bahwa jumlah cabang lebih banyak terdapat pada perlakuan tanpa naungan namun cabangnya lebih pendek sehingga jumlah daun lebih sedikit. Sedangkan pada perlakuan naungan $50 \%$ walaupun jumlah cabang lebih sedikit namun cabangnya lebih panjang sehingga jumlah daun lebih banyak.

Nilam varietas Lhokseumawe menunjukkan Jumlah daun terbanyak dibandingkan dengan varietas Tapaktuan. Hal ini diduga kesesuaian lingkungan tumbuh terhadap varietas Lhokseumawe serta sinar matahari dengan intensitas cahaya yang kurang (ternaungi) pada varietas Lhokseumawe dapat meningkatkan jumlah daun pada tanaman nilam.

\section{Luas Daun}

Hasil penelitian menunjukkan bahwa perlakuan naungan dan varietas berpengaruh nyata terhadap luas daun tanaman nilam umur4, 8, 12 dan 16 MSPT.

Tabel 5. Luas daun tanaman nilam pada umur 4, 8, $\quad 12$ dan 16 MSPT akibat perlakuan naungan $(\mathrm{N})$ dan varietas tanaman $\mathrm{P} 1$ (Tapaktuan), P2 (Lhokseumawe)

\begin{tabular}{|c|c|c|c|c|c|}
\hline \multirow{2}{*}{\multicolumn{2}{|c|}{ Varietas }} & \multicolumn{3}{|c|}{ Naungan } & \multirow{2}{*}{ Rataan } \\
\hline & & N0 & N1 & $\mathrm{N} 2$ & \\
\hline & & \multicolumn{4}{|c|}{$\mathrm{Cm}$} \\
\hline \multirow{3}{*}{\multicolumn{2}{|c|}{$\begin{array}{c}4 \\
\text { MSPT }\end{array} \frac{\mathrm{P} 1}{\text { R2 }}$}} & 16,78 & 21,91 & 25,67 & 21,45 \\
\hline & & 18,64 & 22,20 & 32,48 & 24,44 \\
\hline & & $17,71 \mathrm{c}$ & $22,06 \mathrm{~b}$ & $29,08 \mathrm{a}$ & \\
\hline \multirow{3}{*}{$\begin{array}{c}8 \\
\text { MSPT }\end{array}$} & $\mathrm{P} 1$ & 18,78 & 24,60 & 27,76 & $23,71 \mathrm{~b}$ \\
\hline & $\mathrm{P} 2$ & 21,31 & 23,87 & 31,92 & $25,70 \mathrm{a}$ \\
\hline & Rataan & $20,04 \mathrm{c}$ & $24,23 \mathrm{~b}$ & $29,84 \mathrm{a}$ & \\
\hline \multirow{3}{*}{$\begin{array}{c}12 \\
\text { MSPT }\end{array}$} & $\mathrm{P} 1$ & 26,55 & 27,03 & 34,61 & $29,40 \mathrm{~b}$ \\
\hline & P2 & 27,31 & 28,17 & 39,39 & $31,62 \mathrm{a}$ \\
\hline & Rataan & $26,93 \mathrm{~b}$ & $27,60 \mathrm{~b}$ & $37,00 \mathrm{a}$ & \\
\hline \multirow{3}{*}{$\begin{array}{c}16 \\
\text { MSPT }\end{array}$} & $\mathrm{P} 1$ & 27,54 & 28,83 & 34,22 & $30,20 \mathrm{~b}$ \\
\hline & P2 & 27,25 & 30,11 & 38,33 & $31,90 \mathrm{a}$ \\
\hline & Rataan & $27,40 \mathrm{~b}$ & $29,47 \mathrm{~b}$ & $36,28 \mathrm{a}$ & \\
\hline
\end{tabular}

Keterangan :Angka yang diikuti oleh huruf yang sama pada kolom yang sama tidak berbeda nyata pada taraf $\mathrm{P} \leq=0,05$ (Uji BNJ)

N0 : Tanpa Naungan,

N1 : Naungan $25 \%$,

N2 : Naungan $50 \%$

Perlakuan naungan $50 \%$ diperoleh luas daun yang lebih lebar bila dibandingkan dengan perlakuan naungan $25 \%$ dan tanpa naungan. Prawoto dan Sholeh (2006) menyatakan bahwa ukuran daun tanaman nilam yang diusahakan dibawah penaung lebih lebar dibandingkan daun nilam tanpa naungan. Pemberian naungan mengakibatkan peningkatan luas daun, hal ini sebagai upaya tanaman dalam mengefisiensikan penangkapan energi cahaya untuk fotosintesis secara normal pada kondisi intensitas cahaya rendah (Djukri dan Purwoko 2003). 
Varietas Lhokseumawe menunjukkan luas daun lebih lebar dibandingkan varietas Tapaktuan. Hal ini diduga kesesuaian lingkungan tumbuh terhadap varietas Lhokseumawe serta sinar matahari dengan intensitas cahaya yang kurang (ternaungi) pada varietas Lhokseumawe dapat meningkatkan luas daun pada tanaman nilam.

\section{Kesimpulan Dan Saran}

\section{Kesimpulan}

1. Perlakuan naungan 50\% berpengaruh nyata terhadaptinggi tanaman, diameter pangkal batang, jumlah daun, luas daun. Sedangkan tanpa naungan berpengaruh nyata terhadap jumlah cabang tanaman nilam.

2. Varietas Lhokseumawe menunjukkan pertumbuhan yang lebih baik terhadap tinggi tanaman, diameter pangkal batang, jumlah cabang, jumlah daun dan luas daun.

3. Kombinasi naungan dan varietas tidak mempengaruhi pertumbuhan dan produksi tanaman nilam.

\section{Saran}

Penanaman varietas Nilam Lhokseumawe dengan menggunakan naungan pada awal tanam agar diperoleh pertumbuhan tanaman nilam yang lebih baik.

\section{Daftar Pustaka}

Adinugraha, H.A., Moko, H., dan Cepi. 2006. Pertumbuhan stek pucuk sukun asal dari Nusa Tenggara Barat dengan aplikasi zat pengatur tumbuh. Jurnal Penelitian Hutan Tanaman. Pusat Penelitian dan Pengembangan Hutan Tanaman.Yogyakarta.Vol.3 (2).
Agalave, H.R. 2017. Effect of environmental factors on productivity of crop. International Journal of Botany Studies. Vol. 2 (1), 14-16.

Chen, G. Wang, S. Huang, X. Hong, J. Du, L. Zhang, L. Ye, L. 2015. Environmental factors affecting growth and development of Banlangen (Radix isatidis) in China. African Journal of Plant Science. Vol. 9 (11), pp. 421-426

Direktorat Jenderal Perkebunan. 2017. Statistik perkebunan Indonesia. 2015-2017. Nilam. Direktorat Jenderal Perkebunan, Jakarta. 16 hal.

Djukri dan Purwoko, B. S. 2003. Pengaruh naungan paranet terhadap sifat toleransi tanaman talas (Colocasia esculenta (L.) Schott). Jurnal Ilmu Pertanian 10 (2).

Gardner, F.P., Pearce, R.B., dan Mitchell, R.L. 1991. Fisiologi tanaman budidaya. Universitas Indonesia. Jakarta.

Haryati, R. 2008. Pertumbuhan dan biomassa Spirulina sp. dalam skala laboratoris. Laboratorium Ekologi dan Biosistematik, Jurnal Jurusan Biologi FMIPA. Universitas Diponegoro. Semarang.

Imran.1994. Pengaruh peubah lingkungan fisik terhadap pertumbuhan, hasil dan kandungan minyak nilam. Tesis Pascasarjana Institut Pertanian Bogor.

Lakitan, B. 1996. Fisiologi pertumbuhan dan perkembangan tanaman. PT. Raja Grafindo Persada. Jakarta.

Mangun, H.M.S., Waluyo, H., dan Purnama, S. A. 2012. Nilam; Hasilkan rendemen minyak hingga 5 kali lipat dengan fermentasi kapang. Penebar Swadaya. Jakarta. 
Nuryani, Y., Emmyzar., danWiratno. 2005. Budidaya tanaman nilam.

Badan Penelitian dan Pengembangan Pertanian. Balai Penelitian Tanaman Obat dan Aromatik. Bogor.

Nuryani, Y. 2006. Karakteristik empat aksesi nilam. Balai Penelitian Tanaman Obatdan Aromatik. Buletin Plasma Nutfah. Bogor.

Prawoto, A.A., dan Sholeh, M. 2006. Produksi awal dan kajian ekonomis usahatani nilam aceh (pogostemon cablin Benth.) sebagai tanaman sela kakao muda. Pelita Perkebunan 22 (3). 168-190.

Rahayu, A.Y., dan Harjoso, T. 2011. Aplikasi Abu Sekam pada Padi Gogo (Oryza sativa L.) terhadap kandungan silikat dan prolin daun serta amilosa dan protein biji. Biota. 16 (1): 48-55.

Setiawan., dan Sukamto. 2016. Karakter morfologis dan fisiologis tanaman nilam di bawah naungan dan tanpa naungan. Balai Penelitian Tanaman Rempah dan Obat. Bogor.Vol. 27, 137-146. 